\title{
KONSEPSI PENGETAHUAN MATEMATIS MAHASISWA PROGRAM STUDI PENDIDIKAN MATEMATIKA UNIVERSITAS KANJURUHAN MALANG TAHUN 2015/2016 PADA MATERI GEOMETRI
}

\author{
${ }^{1}$ Maya Safrina, ${ }^{2}$ Puguh Darmawan \\ ${ }^{1,2}$ Program Studi Pendidikan Matematika, FKIP Universitas Kanjuruhan Malang \\ e-mail: ${ }^{1}$ mayasafrina25@gmail.com, ${ }^{2}$ puguhdarmawan212@gmail.com
}

\begin{abstract}
Abstrak
Tujuan penelitian ini untuk mendeskripsikan konsepsi pengetahuan matematis mahasiswa program studi pendidikan matematika universitas kanjuruhan malang pada materi geometri. Pendekatan yang digunakan adalah kualitatif. Jenis penelitian yang digunakan adalah deskriptif eksploratif. Lokasi penelitian di Universitas Kanjuruhan Malang dengan subjek 6 mahasiswa program studi pendidikan matematika. Instrumen penelitian meliputi peneliti, soal tes, rubrik penilaian tes, pedoman wawancara, lembar validasi dan alat rekam. Teknik analisis data meliputi reduksi data, penyajian data dan penarikan kesimpulan. Hasil penelitian ini adalah: (1) dua mahasiswa mengalami miskonsepsi pengetahuan konseptual ukuran ruas garis, (2) tiga mahasiswa mengalami miskonsepsi pengetahuan konseptual ukuran sudut, (3) satu mahasiswa mengalami miskonsepsi pengetahuan konseptual definisi sudut bersuplemen, (4) satu mahasiswa mengalami miskonsepsi pengetahuan konseptual definisi sudut berkomplemen, (5) satu mahasiswa mengalami miskonsepsi pengetahuan konseptual sifat refleksif kongruensi, (6) satu mahasiswa mengalami miskonsepsi pengetahuan konseptual simbol kongruensi sudut, (7) satu mahasiswa mengalami miskonsepsi pengetahuan konseptual definisi dua garis saling tegak lurus, (8) empat mahasiswa mengalami miskonsepsi pengetahuan prosedural dalam memperoleh sudut lurus, (9) satu mahasiswa mengalami miskonsepsi pengetahuan prosedural postulat pengurangan, (10) satu mahasiswa mengalami miskonsepsi pengetahuan prosedural sifat refleksif dan (11) satu mahasiswa mengalami miskonsepsi pengetahuan prosedural kongruensi ruas garis.
\end{abstract}

Kata kunci: Konsepsi, pengetahuan matematis, Geometri.

\section{PENDAHULUAN}

Kemajuan suatu bangsa sangat dipengaruhi oleh tingkat kualitas sumber daya manusia. Peningkatan kualitas pendidikan merupakan bagian yang tidak terpisahkan dalam proses pembangunan suatu bangsa, termasuk di dalamnya adalah pengembangan sumber daya manusia. Menurut Mulyasa (2004:4), pendidikan memiliki kontribusi yang sangat besar bagi kemajuan suatu bangsa serta menjadi wahana dalam menerjemahkan pesan-pesan konstitusi sekaligus sebagai sarana dalam membangun watak bangsa (Nation Character Building). Menurut Rohiyatun (2011: 1), faktor yang sangat menentukan keberhasilan suatu bangsa bukanlah kekayaan alam yang dimiliki, melainkan kualitas sumber daya manusia 
yang dimiliki. Perkembangan SDM Indonesia bisa dikatakan masih rendah. Salah satu upaya agar keberhasilan pendidikan tercapai adalah diperlukannya guru yang memiliki pengetahuan matematis yang baik.

Universitas Kanjuruhan Malang adalah lembaga pendidikan tinggi yang berwatak multikultural dan merupakan wahana bagi generasi muda untuk menyiapka diri menjadi pribadi yang cerdas, terampil, mandiri, mampu menampilkan citra, sikap, semangat dan nilainilai luhur Pancasila serta Undang-undang Dasar 1945, mampu mewujudkan cita-cita proklamasi kemerdekaan serta mampu menjaga keutuhan bangsa dan Negara Kesatuan Republik Indonesia melalui pengembangan ilmu pengetahuan, teknologi dan seni secara mandiri dalam bingkai Bhinneka Tunggal Ika (Pedoman Akademik UNIKAMA, 2014:1).

Alasan pemilihan materi kongruensi segitiga didasarkan pada hasil pengamatan penulis yang mengajar Mahasiswa Program Studi Pendidikan Matematika Universitas Kanjuruhan Malang pada Minggu, 11 Oktober 2015. Hasil pengamatan di kelas menunjukan beberapa fakta, diantaranya adalah terdapat beberapa mahasiswa yang mengalami kesulitan pada materi kekongruenan segitiga pada matakuliah Geometri Euclid. Kesulitan tersebut terjadi karena beberapa faktor yang salah satunya adalah pemahaman mahasiswa yang salah terhadap konsep-konsep pada Geometri Euclid. Sehingga mengakibatkan ketidakmampuan mahasiswa dalam menyusun bukti yang diminta oleh soal.

Dari pengamatan penulis tersebut, maka penulis beranggapan bahwa selama ini mahasiswa masih mengalami miskonsepsi-miskonsepsi pada materi Geometri. Miskonsepsimiskonsepsi mahasiswa pada materi Geometri tersebut dapat dijadikan sebagai informasi dan masukan dalam upaya meningkatkan pengetahuan matematis bagi guru matematika.

Mahasiswa-mahasiswa program studi Pendidikan Matematika Universitas Kanjuruhan Malang 2015/2016 semester 3 adalah mahasiswa-mahasiswa yang telah mempelajari matakuliah-matakuliah tentang pengetahuan matematis dan pengetahuan pedagogis. Di sisi lain, Anne K. Morris dan James Hiebert, (2009:15) dalam penelitiannya menyebutkan bahwa mahasiswa sebagai calon guru belum memiliki pengetahuan konseptual dan prosedural yang baik.

Berdasarkan uraian di atas, peneliti tertarik untuk melakukan penelitian dengan judul Konsepsi Pengetahuan Matematis Mahasiswa Program Studi Pendidikan Matematika Universitas Kanjuruhan Malang Tahun 2015/2016 terhadap Materi Geometri.

\section{METODE}

Berikut ini akan dipaparkan metode dalam penelitian ini.

\section{Pendekatan dan Jenis Penelitian}

Penelitian ini berupaya untuk mendeskripsikan konsepsi pengetahuan matematis mahasiswa Program Studi Pendidikan Matematika Universitas Kanjuruhan Malang Tahun 2015/2016 pada Materi Geometri. Pendekatan yang digunakan pada penelitian ini adalah pendekatan kualitatif. Jenis penelitian yang digunakan adalah deskriptif eksploratif.

\section{Subyek penelitian}


Subyek dalam penelitian ini adalah mahasiswa program studi pendidikan matematika Universitas Kanjuruhan Malang. Subyek penelitian ini dipilih berdasarkan beberapa kriteria yang ditetapkan oleh peneliti untuk mencapai tujuan penelitian. Berikut adalah kriteria Subyek yang akan dipilih.

1. Subyek dalam penelitian ini adalah mahasiswa yang sudah menempuh mata kuliah Geometri.

2. Subyek merupakan mahasiswa berkemampuan tinggi, mahasiswa berkemampuan sedang, mahasiswa berkemampuan rendah yang digolongkan berdasarkan pada nilai tes dan juga mempertimbangkan nilai mata kuliah Geometri yang diperoleh pada semester sebelumnya. Penggolongan ini dilakukan karena tujuan penelitian ini adalah untuk mengetahui kesamaan dan perbedaan mendasar proses konsepsi pengetahuan matematis mahasiswa.

3. Subyek penelitian diambil sebanyak 4 orang yaitu 1 orang berkemampuan tinggi, 1 orang berkemampuan rendah dan 2 orang berkemampuan sedang. Dipilihnya 4 Subyek dari masing-masing tingkat kemampuan disebabkan karena analisis yang digunakan pada penelitian ini adalah analisis perbandingan tetap, dimana peneliti akan menganalisis konsepsi pengetahuan matematis dari masing-masing Subyek dan irisan yang diperoleh dari konsepsi pengetahuan matematis 4 Subyek merupakan karakteristik konsepsi pengetahuan matematis dari kelompok Subyek tersebut, dan kemudian akan dilakukan perbandingan diantara golongan kemampuan mahasiswa. Pemilihan Subyek yang hanya 4 orang dikarenakan keterbatasan peneliti.

4. Subyek diambil dengan mempertimbangkan kemampuan komunikasinya agar pengungkapan konsepsi pengetahuan matematis dapat dilakukan dengan baik dan juga kesediaan mahasiswa untuk mencurahkan waktu dalam penelitian.

\section{Data dan sumber data}

Data penelitian ini adalah respon konsepsi pengetahuan konten pedagogik empat mahasiswa program studi Pendidikan Matematika Universitas Kanjuruhan Malang semester genap tahun 2015/2016 semester 2 .

\section{Instrumen penelitian}

Untuk memperoleh data dalam penelitian ini digunakan instrumen sebagai berikut: (1) Peneliti; (2) Soal tes; (3) Rubrik penskoran; (4) Pedoman wawancara; (5) Lembar validasi.

\section{Prosedur Pengumpulan Data}

Pengumpulan data dilakukan dengan memberikan soal tes kepada mahasiswa untuk diselesaikan, kemudian dari jawaban mahasiswa tersebut akan diberikan skor. Skor tersebut digunakan sebagai dasar pemilihan 4 Subyek penelitian.

Setelah terpilih 4 Subyek penelitian maka peneliti melakukan wawancara terkait dengan jawaban mahasiswa pada tes sebelumnya. Wawancara dilakukan dengan cara mewawancarai Subyek satu persatu hingga didapatkan data yang diinginkan. Pada penelitian ini, peneliti memberikan ruang yang sebebas-bebasnya kepada Subyek untuk mengungkapkan pikirannya dengan bahasa yang bebas. Masalah tempat dan waktu 
pengambilan data juga ditentukan sendiri oleh Subyek agar Subyek merasa nyaman dan bisa berekspresi dengan leluasa.

\section{Teknik Analisis Data}

\section{Analisis data}

Tahapan analisis data adalah sebagai berikut.

\section{a. Reduksi Data}

Tahap pertama dalam menganalisa data adalah mereduksi data. Dalam hal ini, reduksi berarti merangkum, memilih hal-hal pokok, memfokuskan hal-hal penting, mencari tema dan pola serta membuang yang tidak perlu.

\section{1) Respon Mahasiswa dari Soal Tes Kekongruenan Segitiga}

Respon mahasiswa dari lembar kuisioner akan dianalisis dengan menggunakan rubrik penskoran. Berdasarkan rubrik pengetahuan matematis mahasiswa akan dikategorikan ke dalam tiga kategori, yaitu pengetahuan matematis mahasiswa tinggi, pengetahuan matematis mahasiswa sedang dan pengetahuan matematis mahasiswa rendah. Skor total yang diperoleh mahasiswa dihitung untuk menilai kinerja dalam menyelesaikan masalah yang diberikan lalu pengetahuan matematis mereka dikelompokkan berdasarkan level-level berikut ini: (1) Level 3 (pengetahuan matematis tinggi); (2) Level 2 (pengetahuan matematis sedang); (3) Level 1 (pengetahuan matematis rendah)

\section{Penyajian data}

Langkah selanjutnya setelah data direduksi adalah menyajikan data. Data mentah berupa respon mahasiswa dari lembar jawaban tes kekongruenan segitiga disajikan dalam bentuk uraian. Sedangkan data berupa hasil wawancara akan diuraian dalam bentuk transkriptranskrip wawancara beserta uraiannya.

\section{b. Penarikan Kesimpulan}

Tahap terakhir adalah penarikan kesimpulan. Dari data yang telah disajikan dapat ditarik suatu kesimpulan. Kesimpulan yang diperoleh akan dikonfirmasikan dengan teoriteori relevan yang telah ada.

\section{HASIL DAN PEMBAHASAN}

Pada pembahasan ini, akan difokuskan pada temuan penelitian. Temuan penelitian yang pertama ada dua mahasiswa yang mengalami miskonsepsi pengetahuan konseptual tentang ukuran ruas garis. Salah satu faktor penyebabnya adalah kurangnya pengalaman mereka dalam mempelajari konsep tersebut selama perkuliahan ataupun di luar perkuliahan. Seelain itu, hal-hal tersebut dapat terjadi karena kurangnya pengetahuan matematis yang mereka miliki. Temuan kedua adalah Ada tiga mahasiswa yang mengalami miskonsepsi pengetahuan konseptual tentang ukuran sudut. . Hal ini dapat terjadi karena mereka kurang bisa menggunakan prosedur-prosedur dalam mengembangkan pengetahuan konseptual yang mereka miliki. 
Sementara itu, munculnya miskonsepsi dalam pembelajaran dapat mengakibatkan salahnya atau tidak sesuainya pemahaman siswa mengenai konsep tertentu pada saat siswa mempelajari konsep tersebut dan pada saat pembelajaran selanjutnya yang merupakan pengembangan dari konsep tersebut. Hal ini sesuai dengan pendapat Hiebert dan Lefevre (1986) yang mengungkapkan bahwa miskonsepsi terjadi jika peserta didik gagal untuk membangun prosedur-prosedur dari pengetahuan konseptual.

Temuan ketiga adalah ada satu mahasiswa yang mengalami miskonsepsi pengetahuan konseptual tentang definisi sudut bersuplemen. Konsep yang tidak sesuai dengan konsep sebenarnya tersebut telah bertahan dalam pemikirannya dan menyebabkan peningkatan pemahaman mahasiswa terhadap operasi penjumlahan ukuran sudut dan definisi sudut bersuplemen menjadi terhambat. Hal ini sejalan dengan pendapat Hammer (1996) yang menyatakan bahwa miskonsepsi merupakan kesalahan yang terjadi akibat struktur kognitif yang salah, berbeda dari pemahaman para ahli, mempengaruhi pemahaman peserta didik dan harus dihindari untuk meningkatkan pemahaman.

Temuan ke empat adalah ada satu mahasiswa yang mengalami miskonsepsi pengetahuan konseptual tentang definisi sudut berkomplemen. mahasiswa beranggapan bahwa sudut yang besarnya $90^{\circ}$ adalah sudut berkomplemen. Padahal sudut berkomplemen adalah sudut dari hasil penjumlahan yang hasilnya $90^{\circ}$. Konsep S1 tentang definisi sudut berkomplemen tersebut tidak sesuai dengan konsep yang sebenarnya. Dengan kata lain, S1 mengalami miskonsepsi pengetahuan konseptual tentang definisi sudut berkomplemen meskipun S1 juga telah mempelajarinya di Sekolah Menengah Pertama.

Temuan kelima Ada satu mahasiswa yang mengalami miskonsepsi pengetahuan konseptual tentang sifat refleksif kongruensi. Mahasiswa mengalami miskonsepsi sifat refleksif kongrusensi pada matakuliah Geometri, meskipun telah mempelajari materi tersebut pada matakuliah Geometri. Mahasiswa yang mengalami miskonsepsi-miskonsepsi dapat disebabkan oleh kebiasaan mereka pada masalah-maalah pembelajaran matematika yang mereka hadapi, pengaruh prakonsepsi (sebelum adanya konsepsi) dan sumber belajar yang kurang tepat. Hal ini didukung oleh pendapat Suparno (2005:34, dalam Sabil, 2009:15) bahwa beberapa miskonsepsi dapat terjadi karena mahasiswa kurang menguasai materi.

Temuan keenam adalah ada satu mahasiswa yang mengalami miskonsepsi pengetahuan konseptual tentang simbol kongruensi sudut. Beberapa penyebab yang dimungkinkan di antaranya adalah karena prakonsepsi yang kurang baik, pengalaman berpikir yang kurang baik, metode mengajar yang kurang tepat dan lain-lain. Hal ini sejalan dengan pendapat Dimas dan Woro (2015: 68) yang mengungkapkan beberapa penyebab miskonsepsi bersumber dari peserta didik, antara lain (1) prakonsepsi, (2) pemikiran asosiatif, (3) pemikiran humanistik, (4) reasoning tidak lengkap atau salah, (5) intuisi, (6) tahap perkembangan kognitif, (7) kemampuan siswa dan (8) minat siswa.

Temuan ketujuh adalah ada satu mahasiswa yang mengalami miskonsepsi pengetahuan konseptual tentang definisi dua garis yang saling tegak lurus. Pendapat Ma Min Shen (2013) yang menyatakan bahwa konsep peeserta didik dianggap miskonsepsi apabila 
memenuhi beberapa hal, antara lain (1) atribut tidak lengkap, (2) penerapan konsep yang tidak tepat, (3) gambaran konsep yang salah, (4) generalisasi yang salah dari suatu konsep, (5) kegagalan dalam melakukan klasifikasi dan (6) misinterpretasi terhadap suatu obyek abstrak dan proses yang berakibat gambaran yang diberikan tidak sesuai dengan kenyataan sebenarnya.

Temuan kedelapan ada empat mahasiswa yang mengalami miskonsepsi pengetahuan prosedural dalam memperoleh sudut lurus. Miskonsepsi pengetahuan prosedural untuk memperoleh sudut lurus dimiliki S1, S2, S3 dan S4 dapat terjadi karena mahasiswamahasiswa tersebut tidak melakukan prosedur-prosedur perolehan sudut lurus, bahwa langkah-langkah yang mereka tuliskan tidak terurut dari langkah sebelumnya ke langkah selanjutnya. Hal ini sejalan dengan pendapat Zainal (2012) yang menyatakan bahwa pengetahuan prosedural merupakan pengetahuan tentang urutan kaidah-kaidah, prosedurprosedur yang digunakan untuk menyelesaikan soal-soal matematika.

Temuan kesembilan Ada satu mahasiswa yang mengalami miskonsepsi pengetahuan prosedural tentang postulat pengurangan. Data yang dipaparkan menunjukkan bahwa mahasiswa melakukan suatu lompatan prosedur pembuktian sebagai akibat dari postulat pengurangan. Seharusnya mahasiswa juga melakukan suatu lompatan prosedur pembuktian Akibatnya, mahasiswa mengalami miskonsepsi pengetahuan prosedural tentang postulat pengurangan.

Temuan kesepuluh adalah ada satu mahasiswa yang mengalami miskonsepsi pengetahuan prosedural tentang sifat refleksif. mahasiswa tidak dapat menerapkan prosedur yang sesuai untuk memecahkan masalah. Akibatnya, mahasiswa tersebut tidak bisa memodifikasi prosedur dalam pemecahan masalah. Hal ini sejalan dengan pendapat Nisa' (2015) yang menyebutkan beberapa indikator pengetahuan prosedural berdasarkan teori pemecahan masalah Polya, meliputi (1) menerapkan prosedur yang sesuai, (2) mengomunikasikan proses algoritma ke dalam situasi masalah dan (3) memodifikasi prosedur untuk menangani faktor-faktor dalam pemecahan masalah. Tanpa kelancaran prosedur yang memadai, seseorang mengalami kesulitan dalam memperdalam pemahaman mereka tentang ide-ide matematika atau memecahkan masalah matematika. Seseorang yang belajar prosedur tanpa pemahaman, biasanya hanya dapat menerapkan prosedur belajar. Sedangkan seseorang yang belajar dengan pemahaman akan dapat memodifikasi atau menyesuaikan prosedur yang akan digunakan.

Temuan terakhir dalam penelitian ini adalah Ada satu mahasiswa yang mengalami miskonsepsi pengetahuan prosedural tentang kongruensi ruas garis. Pada jawabannya, setelah memperoleh $B C=F E$, mahasiswa masih perlu menggunakan konvers dari definisi kongruensi dua ruas garis untuk memperoleh $\overline{B C}=\overline{F E}$. Ini artinya, ada prosedur yang tidak disebutkan oleh mahasiswa. Sehingga dapat dikatakan bahwa mahasiswa mengalami miskonsepsi pengetahuan prosedural mengenai kongruensi ruas garis. Salah satu faktor penyebab miskonsepsi pengetahuan prosedural tentang kongruensi ruas garis yang terjadi pada mahasiswa adalah mahasiswa tersebut jurang mampu,emgingat infoemasi yang pernah 
disampaikan oleh dosen. Hal ini didukun oleh pendapat Kurnia (2015) yang menebutkan bahwa faktor-faktor yang cenderung mempengaruhi peserta didik dalam memecahkan masalah matematika berdasarkan pengetahuan konseptual dan prosedural yang dimiliki, antara lain peserta didik pada masing-masing tingkat kemampuan memori cenderung sama, yaitu peserta didik hanya bergantung memahami materi yang telah diberikan pengajar saat pembelajaran, peserta didik kurang memahami materi yang diberikan, mettode pembelajaran yang diberikan oleh pengajar kurang menarik dan variatif, peserta didik kurang mampu mengingat informasi yang pernah disampaikan oleh pengajar, kurangnya jumlah dan variasi soal yang diberikan pada siswa. Dari beberapa faktor yang memiliki persamaan tersebut,faktor yang membedakan kadar pengetahuan yang dimiliki masing-masing peserta didik adalah kadar pemahaman materi pembelajaran dan kemampuan materi dalam mengingat kembali informasi yang telah diterima selama pembelajaran.

\section{SIMPULAN DAN SARAN}

\section{Simpulan:}

Berdasarkan kajian terhadap pengetahuan konten pedagogik mahasiswa pada materi Geometri, dapat disimpulkan sebagai berikut.

1. Konsepsi pengetahuan konten pedagogik mahasiswa kelompok atas menunjukkan bahwa mahasiswa sebagai calon guru mengalami beberapa miskonsepsi pengetahuan matematis, yaitu miskonsepsi pengetahuan prosedural tentang prosedur dalam memperoleh sudut lurus.

2. Konsepsi pengetahuan konten pedagogik mahasiswa kelompok tengah menunjukkan bahwa mahasiswa sebagai calon guru mengalami beberapa miskonsepsi pengetahuan matematis, antara lain (1) miskonsepsi pengetahuan konseptual tentang konsep ukuran ruas garis, (2) miskonsepsi pengetahuan konseptual tentang konsep ukuran sudut, (3) miskonsepsi pengetahuan konseptual tentang konsep sifat refleksif kongruensi, (4) miskonsepsi pengetahuan konseptual tentang konsep simbol kongruensi sudut, (5) miskonsepsi pengetahuan konseptual tentang konsep definisi dua garis yang tegaak lurus, (6) miskonsepsi pengetahuan prosedural tentang prosedur memperoleh sudut lurus, (7) miskonsepsi pengetahuan prosedural tentang prosedur postulat penguraangan, (8) miskonsepsi pengetahuan prosedural tentang prosedur sifat refleksif dan (9) miskonsepsi pengetahuan prosedural tentang prosedur kongruensi ruas garis.

3. Konsepsi pengetahuan konten pedagogik mahasiswa kelompok bawah menunjukkan bahwa mahasiswa sebagai calon guru mengalami beberapa miskonsepsi pengetahuan matematis, antara lain (1) miskonsepsi pengetahuan konseptual tentang konsep ukuran ruas garis, (2) miskonsepsi pengetahuan konseptual tentang konsep ukuran ruas garis, (3) miskonsepsi pengetahuan konseptual tentang konsep definisi sudut bersuplemen, (4) miskonsepsi pengetahuan konseptual tentang konsep definisi sudut berkomplemen dan (5) miskonsepsi pengetahuan prosedural tentang prosedur dalam memperoleh sudut lurus.

\section{Saran}

Beberapa saran atau rekomendasi yang dapat diajukan dari hasil penelitian ini adalah sebagai berikut. 
1. Sebagai pendidik, perlu mengembangkan design pembelajaran yang dapat meningkatkan konten pedagogik mahasiswa, termasuk meningkatkan pengetahuan matematis mereka untuk menghindari miskonsepsi yang mungkin terjadi.

2. Bagi calon peneliti selanjutnya, perlu mengembangkan kajian untuk melihat pengetahuan konten pedagogik mahasiswa secara lebih mendalam dengan sudut pandang yang berbeda. Dan lagi, karena kajian ini terbatas pada satu materi tertentu maka perlu dilakukan kajian selain pada materi Geometri.

\section{DAFTAR RUJUKAN}

Abidin, Z. 2012. Pemahaman Konseptual dan Prosedural, (Online), (matunisma.blogspot.co.id/2012/05/pemahaman-konseptual-danprosedural.html?m=1), diakses 22 Juli 2016.

E. Mulyasa. 2004. Kurikulum Berbasis Kompetensi. Bandung: Remaja Rosda karya. Hammer, D. 1996. Misconceptions or P-Primes: How May AlternativePerspectives of CognitiveStructure InfluenceInstructional Perceptions and Intentions?, pp. 97-127, dalam The Journal of Learning Science.

Kurnia, Tri. 2015. Analisi Kemaamppuan Memecahkan Masalah Berdasarkan Pengetahuan Konseptual dan Prosedural Materi Garis Singgung Ditinjau dari Kemampuan Memori Siswa Kelas VIII Semester Genap SMP Negeri 7 Surakarta Tahun Pelajaran 2012/2013. Skripsi. Surakarta: Universitas Sebelas Maret.

Morris, A. K. dan Hiebert, J. 2009. Mathematical Knowledge for Teaching in Planning and Evaluating Instruction: What Can Preservice Teachers Learn, Vol. 40, No. 5, 491529, dalam Journal for Research in Mathematics Education.

Nisa', Nur F. 2015. Analisis Pengetahuan Prosedural Siswa dalam Memecahkan

Permasalahan Matematika Berdasarkan Kemampuan Matematika, (Online), (bufitristkip.blogspot.co.id/2015/06/analisis-pengetahuan-proseduralsiswa.html?m=1), diakses 22 Juli 2016.

Rohiyatun, B. 2011. Pengembangan Sumber Daya Manusia di Perguruan Tinggi Swasta

(Studi Multi Kasus di Universitas Muhammadiyah Mataram dan Institut Keguruan dan Ilmu Pendidikan Mataram), (Online), (karya-ilmiah, um.ac.id/index.php/disertasi/article/view/16281), diakses 22 Agustus 2015.

Shen, M. M. 2013. Miskonsepsi dalam Pembelajaran di Sekolah. Nusa Tenggara Barat: Widya Iswara LPMP NTB.

Suparno, P. 2005. Miskonsepsi dan Perubahan Konsep dalam Pendidikan Fisika. Yogyakarta: PT. Gramedia Widiasarana.

Tim penyusun. 2014. Pedoman Akademik Fakultas Keguruan dan Ilmu Pendidikan Universitas Kanjuruhan Malang 2014/2015. Malang: Universitas Kanjuruhan Malang.Suharna, Hery. 2013. Berfikir Reflective (Reflektive Thinking) Mahasiswa Calon Guru DalamPembelajaran. KNM XVI Unpad. Bandung

Sunaryo. 2011. Taksonomi Berfikir. Bandung : PT. Remaja Rosda Karya 